\title{
An Appraisal of the Legal Framework for Adjudication of Industrial Disputes in Nigeria
}

\author{
Matthew Enya Nwocha \\ Faculty of Law, Ebonyi State University, Abakaliki, Nigeria \\ Email: nwochaenyaeni@gmail.com
}

How to cite this paper: Nwocha, M. E. (2017). An Appraisal of the Legal Framework for Adjudication of Industrial Disputes in Nigeria. Beijing Law Review, 8, 321-333.

https://doi.org/10.4236/blr.2017.83019

Received: July 26, 2017

Accepted: September 17, 2017

Published: September 20, 2017

Copyright $\odot 2017$ by author and Scientific Research Publishing Inc. This work is licensed under the Creative Commons Attribution International License (CC BY 4.0).

http://creativecommons.org/licenses/by/4.0/

\section{(c) (i) Open Access}

\begin{abstract}
This paper is titled "An Appraisal of the Legal Framework for Adjudication of Industrial Disputes in Nigeria" and came against the background of the perennial dispute between labour and employers of labour, particularly the public sector, namely, employment under the Federal, State and Local Governments. Agitations for wage increases and improvement of conditions of service by labour have had to face up with government apparent insensitivity to the plight of labour. The results of these frequent disagreements have been the disruption in the industrial sector, low productivity of labour and retarded economic growth. Hence, this paper is aimed at addressing these negative outcomes by evaluating the framework as well as procedure for settlement of industrial disputes in the country with a view to achieving better industrial harmony. The paper has identified three principal legislations that are relevant to adjudication of industrial disputes in the country, namely, the 1999 Constitution of Nigeria (Third Alteration Act) 2010; the National Industrial Court Act, 2006; and the National Industrial Court of Nigeria (Civil Procedure) Rules, 2016. The paper has appraised the strengths and weaknesses of these legislations as well as the factors that militate against their capacity to accomplish their common objective of achieving harmony and stability in the labour sector. To remove these setbacks the paper has recommended among others things, the amendment of the extant laws to attain the best ends of justice and to restore and sustain the confidence of litigants in the adjudication process, which is key to avoidance of frequent strikes and lock-outs.
\end{abstract}

\section{Keywords}

Labour Law, Industrial Dispute, Rules of Court, International Best Practice, Public Trustee, Assessors, Referees, Adjudication, Industrial Court, Electronic Filing, Jurisdiction 


\section{Introduction}

In Nigeria, there are about ten labour related legislations that are currently operational ${ }^{1}$. The legislations are in general terms aimed at securing a functional, harmonious, stable, peaceful and productive labour environment that is conducive to economic growth ${ }^{2}$. These legislations include the Nigerian Constitution, Labour Act, Employees' Compensation Act, Trade Unions Act, Trade Disputes Act, Factories Act, Trade Unions (Amendment) Act, Docks (Safety of Labour) Regulations, National Industrial Court Act and the National Industrial Court Rules. Section 254 A-F of the 1999 Constitution of Nigeria ${ }^{3}$ creates the National Industrial Court and confers it with jurisdiction and powers which have been elaborated under the National Industrial Court Act and the National Industrial Court Rules. The Labour Act contains provisions regarding the protection of wages, contracts of employment and terms and conditions of employment ${ }^{4}$. The Employees' Compensation Act ${ }^{5}$ repealed the Workmen's Compensation Act of 2004 and made provisions for compensation for any death, injury, disease or disability arising out of or in the course of employment. The Trade Unions Act, 1973, made provisions with respect to the formation, registration and organization of trade unions, federation of trade unions and the central labour organization $^{6}$. The Trade Unions (Amendment) Act, 2005, amended the principal Act, that is, the Trade Unions Act (1973), thereby filling up gaps in the law that were necessary for a more efficient operation and co-ordination of trade unionism. The substance of the amendment was to highlight the voluntariness of membership of trade unions; enhance the financial liquidity of trade unions through mandatory membership subscription for effective and impactful operation; and streamline the process of collective bargaining 7 . The Trade Disputes Act of 1976 makes a provision for the settlement of trade disputes and other ancillary matters $^{8}$. The Factories Act of 1987 makes a provision for the registration, obligations of management and operations of factories, as well as the safety of workers. The Docks (Safety of Labour) Regulation mandates the provision of health, medical aid as well as safety infrastructures on the nation's seaports ${ }^{10}$. The Na-

\footnotetext{
${ }^{1}$ See also Uvieghara (2001) Labour Law in Nigeria. Lagos: Malthouse Press Ltd. p.2.

${ }^{2}$ See further Macintyre (2008) Business Law. Essex, England: Pearson Education Limited. Pg 155; Chandra (2008) Business Law. New Delhi: PHI Learning Private Limited, p. 411-413.

${ }^{3}$ As specifically amended by the Third Alteration Act, 2010, passed by the National Assembly, otherwise referred to as Act No. 3, 2010.

${ }^{4}$ The Labour Act (1974) No. 21 passed by the National Assembly effectively repealed and replaced the Labour Code Act and consolidated the law relating to labour. Its provisions took effect from $1^{\text {st }}$ August, 1971.

${ }^{5}$ Act No. 13, 2013, passed by the National Assembly.

${ }^{6}$ The Trade Unions Act is an Act of the National Assembly that came into operation on $1^{\text {st }}$ November 1973.

${ }^{7}$ The Trade Unions (Amendment) Act (2005) took effect on $30^{\text {th }}$ March, 2005. It is, like the principle Act, an Act of the National Assembly.

${ }^{8}$ The Trade Disputes Act (2006) which is an Act of the National Assembly has been amended several times including in 1977, 1988, 1992 and 2006.

${ }^{9}$ The commencement date of the Factories Act (1987), an Act of the National Assembly, is $11^{\text {th }}$ June, 1987.

${ }^{10}$ These seaports are specified under the Regulations to include Lagos, Port Harcourt, Tiko, Sapele, Burutu, Calabar, Warri, Aboea/Degema, Koko Town and Victoria Ports.
} 
tional Industrial Court Act, 2006 ${ }^{11}$, was created by the National Assembly in compliance with section 254 of the 1999 Constitution and elaborates on the establishment, powers and jurisdiction of the National Industrial Court among other things. The National Industrial Court of Nigeria (Civil Procedure) Rules, 2016 were issued by the President of the National Industrial Court of Nigeria pursuant to the powers conferred on him by section 254 (F) (I) of the 1999 Constitution as amended by the Third Alteration Act, 2010; and section 36 of the National Industrial Court Act, 2006. The 2016 Rules revoked the 2007 National Industrial Court Rules and the 2012 Practice Direction. The substance of the 2016 Rules is the regulation of practice and procedure of the National Industrial Court.

It is the National Industrial Court that currently has exclusive jurisdiction to adjudicate over sundry dimensions of labour disputes in Nigeria following the rules of practice and procedure issued under the hand of the president of the court. According to Article 4 of the Rules of the National Industrial Court, the Rules are intended to establish an enduring, equitable, just, fair, speedy and efficient fast-track case management system for all civil matters within the jurisdiction of the court, and promote the socio-economic importance of the jurisdiction of the National Industrial Court among other things. The paper therefore aims at evaluating relevant provisions of the National Industrial Court Act and the National Industrial Court Rules with a view to making a determination whether these legislations can enable the industrial court to put into effect the labour and industrial laws that come within its jurisdiction; especially against the background of the persistent antagonism between employees and employers of labour in Nigeria ${ }^{12}$. The paper also seeks to establish the larger implications of the adjudicatory process on economic growth in the country. To achieve these objectives, the paper is segmented into four sections: 1) Introduction, 2) Legal Framework for Resolution of Industrial Disputes, 3) Recommendation and 4) Conclusion. The research has both social and academic significance. The social significance lies in the fact that when the recommendations are implemented, the result will be economic empowerment for the employees and their families, social and industrial harmony in the work place, and enhanced labour productivity which would boost the economy. The academic significance on the other hand, lies in the fact that the research would have contributed to a deeper knowledge of the subject and the potential strengthening of the laws under study.

\section{Legal Framework for Resolution of Industrial Disputes}

The machinery for the adjudication of industrial disputes in Nigeria originates from the 1999 Constitution, the country's grundnorm, as amended by the Third Alteration Act, 2010. Section 254 A (1) establishes the National Industrial Court while Section 254 A (2) details its composition to include the President of the

\footnotetext{
${ }^{11}$ Act No. 17, 2006. It came into force on $14^{\text {th }}$ June, 2006.

${ }^{12}$ See also Fashoyin (1992) Industrial Relations in Nigeria, $2^{\text {nd }}$ ed. Lagos: Longman Nigeria Plc. p. 1.
} 
court with the power of management, control and supervision of the court as well as regulation of its practice and procedure ${ }^{13}$; and such number of Judges as many be prescribed by an Act of the National Assembly ${ }^{14}$. The National Industrial Court has both civil and criminal jurisdictions. Section 254C of the Constitution specifies the civil jurisdiction of the industrial court including that it shall have and exercise jurisdiction to the exclusion of any other court in civil cases and matters:

a. relating to or connected with any labour, employment, trade unions, industrial relations and matters arising from work place, the condition of service, including health, safety, welfare of labour, employee, worker and matters incidental thereto or connected therewith;

b. relating to, connected with or arising from Factories Act, Trade Disputes Act, Trade Unions Act, Labour Act, Employees' Compensation Act or any other Act or law relating to labour, employment, industrial relations, workplace or any other enactment replacing the Acts or laws; and

c. relating to or connected with the grant of any order restraining any person or body from taking part in any strike, lock-out or any industrial action or any conduct in contemplation or in furtherance of a strike, lock-out or any industrial action and matters connected therewith or related thereto.

The court shall also determine any question as to the interpretation and application of any collective agreement; award or order made by an arbitral tribunal in respect of a trade dispute or a trade union dispute; award or judgment of the court; terms of settlement of any trade dispute, trade union dispute or employment dispute as many be recorded in a memorandum of settlement; trade union constitution, the constitution of an association of employers or any association relating to employment, labour relations or work place dispute relating to or connected with any personnel matter arising from any free trade zone in the federation or any part thereof; and disputes arising from payment or nonpayment of salaries, wages, pensions, gratuities, allowances, benefits and any other entitlement of any employee, worker, political or public office holder, judicial officer or any civil or public servant ${ }^{15}$. The court is also empowered to deal with any matter connected with or pertaining to the application of any international convention, treaty or protocol of which Nigeria has ratified relating to labour, employment, work place, industrial relations and other connected matter ${ }^{16}$. The court can further establish alternative dispute resolution within the court premises to deal with matters within its jurisdiction ${ }^{17}$.

\footnotetext{
${ }^{13}$ Section 1(2) (a) of the National Industrial Court Act, 2006 and section 254 F(1) of the 1999 Constitution as amended by Act No. 3, 2010.

${ }^{14}$ Section 1(2) (a) of the National Industrial Court Act, 2006, which is an Act of the National Assembly specifies the number of Judges as not less than twelve. However, by section 254E (1) of the Constitution, Third Alteration Act No. 3, 2010, for the purpose of exercising its jurisdiction, the court shall be duly constituted if it consists of a single Judge or not more than three Judges as the President of the court may direct.

${ }^{15}$ Section $254 \mathrm{C}(1)(\mathrm{j})$ and $(\mathrm{k})$.

${ }^{16}$ Section 254C (2) of the Constitution, Third Alteration Act, No. 3, 2010.

${ }^{17}$ Section 254C (3) of the Constitution, Third Alteration Act No. 3, 2010.
} 
Section 254 C (5) of the Constitution, Third Alternation Act. 2010, empowers the court to have and exercise jurisdiction and powers in criminal causes and matters. And for the purposes of exercising its criminal jurisdiction, the president of the court may hear, determine, or assign a single Judge of the court to review such matters ${ }^{18}$. Furthermore, the Constitution authorizes the court, when exercising its criminal jurisdiction to apply the provisions of Nigeria's principle criminal statutes, namely, the Criminal Code, Penal Code, Administration of Criminal Justice Act, and the Evidence Act ${ }^{19}$. Again, for the purposes of exercising its jurisdiction, the court has powers equivalent to that of a High Court ${ }^{20}$. Section 11(1) of the National Industrial Court Act, 2006, forbids any other courts with the exception of courts sitting on appeal over decisions of the Industrial Court, such as the Court of Appeal or the Supreme Court, from entertaining matters within the exclusive jurisdiction of the Industrial Court. Furthermore, the Industrial Court has the power to enforce its judgment, and may commit for contempt any person or a representative of a trade union or employers' organization who commits any act or omission which in the opinion of the court constitutes a contempt of the court ${ }^{21}$. Aside of judgment that the court can enter, it can also grant injunctions, make orders for mandamus, prohibition or certiorari, grant urgent interim reliefs, declaratory orders, appoint a public trustee for the management of the affairs and finances of a trade union or employers' organization involved in any organizational dispute, award compensation and damages in appropriate cases, and order compliance with any provision of any Act of the National Assembly dealing with any matter that the court has jurisdiction to hear and determine ${ }^{22}$. Again, Section 20 of the National Industrial Court Act empowers the court to promote reconciliation and amicable settlement of matters.

From the provisions of the enabling laws, it would appear that the Industrial Court is well positioned to adjudicate disputes arising from Nigerian labour laws in the interest of industrial peace and harmony, as well as enhanced productivity and economic growth. This would have been the case if not for certain problems inherent in the Act creating the Court and the Rules of practice made thereto that militate against the attainment of this objective. Among the problems are the ambivalence of certain provisions of the enabling Act and the Rules made thereto, as well as the almost limitless discretion allowed the Judges of the Court to call in aid one or more assessors specially qualified and to try and hear any matter or cause wholly or partially with the aid of such assessors. Section 29(2) says that assessor(s) shall be paid such remunerations as the court shall determine. But section 29 is regrettably shy of the criterion for determining the eligi-

\footnotetext{
${ }^{18}$ Section 254E (2) of the Constitution, Third Alteration Act No. 3, 2010.

${ }^{19}$ Section $254 \mathrm{~F}(2)$ of the Constitution, Third Alteration Act No. 3, 2010.

${ }^{20}$ In practice, Nigerian High Courts have unlimited jurisdiction in civil and criminal matters. See further Section $254 \mathrm{D}(1)$ of the Constitution, Third Alteration Act, No. 3, 2010.

${ }^{21}$ Section 10 of the National Industrial Court Act, 2006.

${ }^{22}$ Sections 16, 17, 18 and 19 of the National Industrial Court Act, 2006.
} 
bility of such assessors, what their special qualification should be, and the procedure for their appointment. Again, section 30 (1) authorizes the court to refer to an official or special referee for inquiry or report any question arising in any cause or matter while section 30(2) mandates that the report of such an official or special referee may be adopted wholly or partially by the court and, if so adopted, may be endorsed as a judgment or order to the same effect. It is perplexing that section 54 which is the interpretation section of the act does not define, or even illustrate, who an official or special referee is or their eligibility for appointment. The Act leaves us to speculate whether the official or special referee is an officer of the court, public service or otherwise. If his or their report can potentially be adopted by the court as judgment, then there is every need to appoint only an impartial arbiter to avert any affront to justice. But this does not appear to be the case, for in reality the Judge may appoint whomsoever that pleases him to actualize a predisposed mindset in certain cases. Accordingly, it is the employee who finds himself helpless in the end. With a judiciary appointed and controlled by the executive branch in the country, this creates loopholes for Judges to carry out the whims of their appointers and benefactors resulting more often than not in government as well as wealthy employers being able to hire and fire employees at will thereby swelling the army of the unemployed with dire consequences for the economy.

Another curious provision of the National Industrial Court Act is section 36 which in complementarity with section $254 \mathrm{C}$ of the Constitution, Third Alteration Act, 2010, empowers the President of the Court to make rules for effecting the provisions of the Act. Section 36(2) of the said Industrial Court Act stipulates that the rules of court so made shall apply to all proceedings by or against the government of the Federation, State, or Local Government. There is a deafening silence on what happens when the court is presiding over a matter between employers of labour in the private sector and their employees. This is a huge lacuna that can only lead to the dissipation of energy and time on technical arguments in court while victims of breaches of employment obligations continue to bear the consequences of delayed justice. All the labour laws in the country which have been mentioned in the introduction to this Paper make no distinction in application between the public and private sectors of the economy. This makes section 36(2) of the Industrial Court Act even more intriguing.

Again, section 254F (2) of the Constitution, Third Alteration Act, 2010, makes mandatory the application of the Evidence Act when the court is exercising its criminal jurisdiction but there is no mention of what happens when it is exercising its civil jurisdiction. In relation to this, section 12 (2) (b) of the National Industrial Court Act, 2006, states that the court shall be bound by the Evidence Act but may depart from it in the interest of justice. It is a reasonable inference that by the Constitution, Third Alteration Act, the court exercising its civil jurisdiction may adopt any approach and admit any evidence it deems fit or proper ostensibly in the interest of justice. The provision is rather erroneous and 
groundless in law. It can result in arbitrariness and inconsistencies in the scope and quality of evidence admitted even within the same trial and in subsequent trials of related matters. This is an outcome that the Evidence Act is designed to forestall. Allowing the Judge to follow or jettison it at will only grants him unlimited discretion which would obviously work against the employee in a country where Judges are only too eager to pander to the dictates of government, the largest employer of labour. Furthermore, allowing the Judge to depart from the Evidence Act in the interest of justice appears to be a contradiction in terms. It is our view that the Evidence Act is designed to protect the interest of justice. As such, departing from it cannot achieve the same effect. The safest and best justice is one according to law and not according to discretion. Discretion, however conceived, ultimately embodies the Judge's idiosyncrasies, his background and social orientations. The combined effect of section 254F (2) of the Constitution and 12 (2) (b) of the Industrial Court Act weakens the confidence of litigants in the adjudicatory process and impacts negatively on the commitment and productivity of labour. The economic implication of this is huge. A demoralized labour force is predisposed to corruption and fraud, all of which impact negatively on the economy.

Furthermore, section 13 of the Industrial Court Act states that inevery civil cause or matter commenced in the court, law and equity shall be administered by the court concurrently. Similarly, section 15 of the Act authorizes the application of common law, save that in the event that the rules of common law and the rules of equity conflict on any matter, the rules of equity shall prevail. Now with equal prominence and strength of application given to labour statutes and common law and equity, the presiding Judge is allowed too much airs to pick and choose which one of them apply to any set of circumstances depending on what he thinks serves the best interest of justice. In other words, the application and enforcement of labour laws ultimately depends upon his discretion. There is a likelihood that this situation might result in the sounding of discordant tunes from the judiciary when it comes to the resolution of labour disputes. Common law, in the final analysis, is nothing more than English customary law ${ }^{23}$ and equity merely indulges an individual's sense of what is fair and just. Abbott et al. have stated that common law is the common sense of the community as formulated by the ancestors and that it is neither local law nor the result of legislation $^{24}$.

There is a further unresolved issue about the status of the National Industrial Court within the Nigerian judicial hierarchy. Section 1 (3) of the National Industrial Court Act, 2006, proclaims it a superior court of record and confers it with all the powers of a High Court. But the apex court in Nigeria, the Supreme Court, in 2010, approximately four years after the Industrial Court Act took ef-

${ }^{23}$ Nwocha (2016) "Customary Law, Social Development and Administration of Justice in Nigeria," Beijing LawReview, 2016, 7, 430-442. http://www.scirp.org/journal/bir./ISSN Online: 2159-4635. ${ }^{24}$ Abbott, Pendlebury, \& Wardman (2013) Business law ( $9^{\text {th }}$ Ed.) Hampshire, UK: Cengage Learning EMEA.Pg. 35. 
fect, held in National Union of Electricity Employees vs. Bureau of Public Enterprises $^{25}$ that the National Industrial Court was not a superior court of record. The court cited, correctly in our view, sections 6(3) and 6(5) of the 1999 Constitution which declared and listed the superior courts of record and did not include the National Industrial Court. The Supreme Court did not stop there for it proceeded to pronounce the National Industrial Court as being inferior and subordinate to the High Court notwithstanding the contents of the National Industrial Court $\mathrm{Act}^{26}$. Conscious of this complication, the National Assembly in 2010 attempted to restore the status of the National Industrial Court as a superior court of record by injecting section $254 \mathrm{~A}-\mathrm{F}$ into the Constitution to give constitutional backing to the National Industrial Court; establishing it and granting it powers, jurisdiction, procedure and other ancillary enablements ${ }^{27}$. However, the amendment did not clearly state that the National Industry Court was a superior court of record, nor did it list it as one of the superior courts of record. The only provision relevant to the powers or status of the Industrial Court in the Third Alteration Act is section 254D (1) stating that: for thepurpose of exercising any jurisdiction conferred upon it by this Constitution or as may be conferred by an Act of the National Assembly, the National Industrial Court shall have all the powers of a High Court.

This is curious because jurisdiction is clearly different from status. That you can do what something or someone else can do does not place you in the same status with that other thing or person. It is inexplicable why the National Assembly was shy of pronouncing the court as a superior court of record, if this was their intention. The 1999 Constitution, Third Alteration Act, did not also list the court as being among superior courts of record ${ }^{28}$. And so, merely giving it the powers of a High Court has not completely resolved the controversy generated by the Supreme Court cases of National Union of Electricity Employees vs. Bureau of Public Enterprise ${ }^{29}$, Attorney-General of Oyo State vs. Nigeria Labour Congress $^{30}$, and similar court decisions. This is a controversy that only the Supreme Court itself can settle by a future pronouncement in the light of the Third Alternation Act to the 1999 Constitution. But whether this matter is given a final settlement or not, most courts would probably consider it a mere technical argument and proceed to equate the National Industrial Court with the High Court and assume that they have co-jurisdiction. Such position would certainly find support in a community reading of section $254 \mathrm{D}$ of the Third Alteration Act to the 1999 Constitution, and section 1(2) of the National Industrial Court

\footnotetext{
${ }^{25}(2010) 4$ NSCQR 611 at 619 ratio 8.

${ }^{26}$ See also Attorney-General of Oyo State vs. Nigeria Labour Congress (2003) 8 NWLR (Pt. 821)1 at 3 which the Supreme Court decided in similar fashion.

${ }^{27}$ See the Third Alteration Act, No. 3, 2010 to the 1999 Constitution.

${ }^{28}$ There have been only three Alterations to the 1999 Constitution to date vide the First, Second and Third Alteration Acts. Neither the First or Second Alteration Acts mentioned anything about the National Industrial Court.

${ }^{29}$ Supra.

${ }^{30}$ Supra.
} 
Act, 2006. Notwithstanding this, the point has to be made that the uncertainty generated by this legislative ambiguity would continue to becloud the Industrial Court and impact unfavourably on its prestige and the confidence that litigants may repose in it, at least until the Supreme Court finds the opportunity to settle the debate with finality or until the National Assembly gets a chance to clear the matter. Until this happens, organized labour is more likely than not to invest trust in strikes and lock-outs as a way of forcing the hands of their employers to pay attention to their welfare needs than in the adjudicatory process and in the end productivity of labour will be low and economic growth will be retarded.

As it relates to procedure, the National Industrial Court of Nigeria (Civil Procedure) Rules, 2016, are the extant rules of court for the adjudication of industrial disputes in Nigeria. The Rules which came into effect on $5^{\text {th }}$ day of January, $2017^{31}$, were intended to establish an enduring equitable, just, fair, speedy and efficient fast-track case management system for all civil matters within the jurisdiction of the court taking into account, among other things, the socio-economic importance of the jurisdiction of the court ${ }^{32}$. The Rules were also aimed at facilitating the integration of alternative dispute resolution (ADR) into the adjudicatory mechanism; expanding and providing easier and fairer access to justice for all classes of parties, promoting reconciliation and encouraging and facilitating amicable settlement of disputes ${ }^{33}$. To bear through its objectives, the 2016 Rules introduced innovations that were not contained in the 2007 Rules. These include provisions for electronic filing of documents under Order 6A; prohibiting sexual harassment and discrimination in the workplace under Order14; enforcement of international protocol, convention and treaty under Order 14A; non-suiting a party rather than dismissing his claims or suit under Order 46; and the appointment of a public trustee under Order 59.

The opportunity created for electric filing of documents can work to speed up the process of filing, administration and adjudication or resolution of disputes ${ }^{34}$. This innovation introduced by the 2016 Rules is one of the first steps in this area for in most Nigerian courts case management is still bogged down by heaps of hard copies of documents that have to be filed and served at all levels ranging from trial courts to appellate courts. The electronic documentation mechanism is therefore a welcome and positive development. Also welcome is the specific attention which the 2016 Rules have paid to the prevalence of sexual harassment and discrimination in the workplace. Sexual harassment is a pervasive problem in the workplace in Nigeria, occurring in both public and private sectors. But in implementing the law on the subject, the courts should not lose sight of the fact that sexual harassment or sexual influence can emanate from both the employer

\footnotetext{
${ }^{31}$ Section 2 of the Industrial Court Rules, 2016. Again section 1 of the 2016 Rules revoked the National Industrial Court Rules, 2007, and the subsequent Practice Direction of 2012.

${ }^{32}$ Section 4 of the 2016 Rules.

${ }^{33}$ Sections 5(4) and 6(1) of the 2016 Rules.

${ }^{34}$ Note that certain specified documents are still mandated to be filed in hard copies such as documents for use in chamber or presentation in camera and documents restricted by law. See Order 6A Rule 2 of the 2016 Rules.
} 
and employee and from both senior and junior staff. In certain cases, sex might be a weapon in the hands of some persons of loose morals to attain desired ends and the courts must be well informed about this. Again, the provision on enforcement of international treaties and protocols is a healthy one. It creates opportunities for the labour in Nigeria to take advantage of international agreements to enhance the welfare of its members. At the same time, it exposes labour to universal ethics and international best practices including the creation of value for money had and received, as well as qualitative output and productivity. The introduction of non-suit as a remedy under the rules impacts positively on the quality and content of justice that may be obtained at the industrial court. Some claimants at the industrial court are not well-informed and may not have the wherewithal to obtain competent legal services. As such, they might come to court with blunders and technical errors on their documents or in their presentation. In such a situation, it is best that they are non-suited rather than have their claims dismissed on technical grounds. They would thereafter have an opportunity to represent their case for a fair and just determination. Furthermore, the appointment of a public trustee under the 2016 Rules, though controversial, can serve some useful purpose in circumstances where a trade union is enmeshed in a leadership dispute. It can bridge the gap or fill the vacuum in leadership and help to stabilize the organization or trade union until peace and normalcy returns.

Aside from the above innovations, there are other positive contents of the Rules such as the reference of dispute to the Alternative Dispute Resolution Centre established within the court premises pursuant to section $254 \mathrm{C}$ (3) of the 1999 Constitution as amended by the Third Alteration Act, 2010 and Article 4 (5) (a)-(e) of the Instrument of the Alternative Dispute Resolution Centre. The Rules mandate that any such referred dispute must be settled through mediation or conciliation within twenty-one working days, though the court may extend the time by ten working days. Where parties agree and settle, a report of such amicable settlement shall be made to the court by the Alternative Dispute Resolution Centre and the court shall by notice invite parties to adopt same and thereafter enter same as the judgment of the court ${ }^{35}$. The alternative dispute resolution procedure is more enduring and saves time and money. It is also less rancorous and because it ends in amicable settlement parties are more willing to implement the terms and fulfill their own part of the bargain ${ }^{36}$. Furthermore, the use of assessors and expert witnesses by the court under Order 28 on the one hand and the use of referees and arbitrators under Order 29 on the other definitely can impact positively on the quality of judgment, and for that matter justice, that the court can offer. Similarly, filing fees required by the Rules for lodgment of documents are quite affordable. To use an illustration, to file an originating process costs Five Hundred Naira; Motion on Notice costs Two

${ }^{35}$ See Generally Order 24, National Industrial Court of Nigeria (Civil Procedure) Rules, 2016.

${ }^{36}$ See further Candide-Johnson \& Shasore (2012) Commercial Arbitration Law and International Practice in Nigeria. Pietermaritzburg: Interpak Books. Pgs 7-11. 
Hundred Naira; Motion Exparte costs Two Hundred Naira and the fee for registration of judgment is Two Hundred Naira ${ }^{37}$. In addition, under Order 52, indigent parties or claimants can file their claims under forma pauperis and the court can assign such matters to legal practitioners willing to undertake same on probono. In this way, indigency might not frustrate the genuine or meritorious claims of a party.

There are certainly many good things to say about the 2016 Rules. But that is not the end of the matter because there are definitely certain controversial, if not unjustifiable, aspects of the Rules that can militate against the attainment of its objectives; and beyond that, against the attainment of the objectives of the National Industrial Court Act itself. These setbacks include the provisions in Order 5 Rule 3 that the court may direct a departure from the Rules where the interest of justice so required; and Order 1 Rule 9 (2) that authorize the court to apply the Rules as it thinks fit and to depart even from the rules of evidence in the interest of justice. These are manifestations of the unbridled discretion placed on the laps of Judges of the Industrial Court by the National Industrial Court Act of which we have earlier in the Paper expressed apprehension to the end that such unguarded discretion can only result in the rule of man and not the rule of law such that whatever the Judge perceives as just becomes just and forms the basis for any judgment or award that he may issue. There is again the question of the appointment of a public trustee under Order 59 of the Rules. As good as the public trustee might be in the securement of peace, stability and continuity in labour unions, his office and terms of appointment should have been a creation of a substantive law and not that of procedural or adjectival law such as the rules of court. The office of public trustee is not a creation of the Constitution or the National Industrial Court Act. By creating and injecting it into the National Industrial Court of Nigeria (Civil Procedure) Rules, 2016, the President of the National Industrial Court acted ultra vires of the powers conferred on him by section $254 \mathrm{~F}$ of the 1999 Constitution as amended by the Third Alteration Act, 2010, and section 36 of the National Industrial Court Act, 2006. Order 59 of the Rules is therefore in conflict with the foregoing superior and substantive laws.

Furthermore, the allowances payable to witnesses are rather paltry and pose a huge constraint on the attendance to court of such witnesses. These are experts and highly placed professional people who are required to attend court in spite of their schedules. And for a full day in court their allowance range from Two Hundred to Five Hundred Naira, where the exchange rate is about Four Hundred Naira to one US dollar ${ }^{38}$. Both the court and the parties will discover that not many witnesses would willingly attend court under such circumstances. And if the court decided to use its power of subpoena, it would sooner discover the backlash that an unwilling and disgruntled witness can bring to bear in court

\footnotetext{
${ }^{37}$ See generally Order 67 of the 2016 Rules. Note that the exchange rate of the Naira is about Four Hundred Naira to the US Dollar.

${ }^{38}$ See Order 67 Rule 1 (2) of the 2016 Rules and Appendix 2 thereto.
} 
proceedings. In the end, it is only the parties that would suffer the outcome of any miscarriage of justice.

\section{Recommendation}

For effective adjudication of industrial disputes in Nigeria, the principal legal instruments, namely, the Constitution of Nigeria; the National Industrial Court Act, 2006; and the National Industrial Court of Nigeria (Civil Procedure) Rules, 2016 should be amended or altered by the National Assembly to remove certain provisions that militate against the attainment of their set objectives and add other elements that would enhance the efficiency of indusial disputes adjudication in the country. Accordingly, it is recommended that section 6 of the Nigeria Constitution dealing on judicial powers be amended to specify and add the $\mathrm{Na}$ tional Industrial Court to the list of superior courts of record therein. This, when done, would avert and finally settle the lingering controversy concerning the status of the court in the judicial hierarchy that became manifest in National Union of Electricity Employees vs. Bureau of Public Enterprise and similar cases. Second, section 36 (2) of the National Industrial Court Act, 2006, should be amended to apply the rules of court to labour relations in the private sector rather than restrict it to the public sector. Third, the terms official referee and special referee should be clearly defined and injected into section 54 which is the interpretation section of the National Industrial Court Act. Again, their appointment should not lie completely at the discretion of the presiding Judge. Fourth, section 12 (2) (b) of the National Industrial Court Act, 2006, should be amended to specify the circumstances under which the court may depart from the provisions of the Evidence Act. This would curb the excessive discretion placed on the Judge. Similarly, section 13 of the Act should be amended to give pre-eminence to a statute and clearly defined contracts over equity. To place the rules of equity on equal play ground with these two, panders to the unlimited discretion of the Judge which is not healthy for fair, valid and consistent court decisions.

With respect to procedure, it is recommended that Order 5 Rule 3 and Order 1 Rule 9 (2) be amended to specify the circumstances under which the Judge may depart from the rules of court and the Evidence Act respectively. This is to ensure judgment is delivered based purely on the facts and the law and also to instill confidence in the minds of litigants that they can obtain justice where the facts and the law are on their side. Again, Order 59 of the Rules should be amended to revert the authorization for the appointment of the public trustee to the National Industrial Court Act. The President of the Court cannot lawfully assume the powers to so appoint as is presently the case. Considering the far-reaching powers of the public trustee as interim administrator of the labour union, such power to appoint ought to be conferred on him by an Act of the National Assembly and not by the Rules he made by himself. Lastly, the allowance payable to assessors, referees and witnesses generally under Order 67 and Sche- 
dule 2 to the 2016 Rules should be reviewed upward to take adequate care of the actual expense incurred by witnesses in attending court. This would enable them do so willingly and also co-operate effectively with the court when they do attend.

\section{Conclusion}

This work has studied and evaluated the legal frameworks for adjudication of industrial disputes in Nigeria. A fair and just determination of industrial disputes is a sine quo non for industrial peace and stability which, again, ultimately impacts positively on output and economic growth. The principal legal frameworks for adjudication of industrial disputes in Nigeria are the 1999 Constitution of Nigeria as amended by the Third Alteration Act, 2010; the National Industrial Court Act, 2006; and the National Industrial Court of Nigeria (Civil Procedure) Rules, 2016. The laws and Rules mentioned above have taken comprehensive steps to ensure harmony in the industrial sector for better output and economic growth. But there are still inherent setbacks that have been examined in the Paper and a number of recommendations offered to enable both laws and the Rules stand up to their bidding for better labour relations and economic growth in the country. This research work is based purely on a study of the legislations mentioned above and the case law that is the outcome of their implementation. There is still need to carry out a further empirical research to determine the degrees of social impact of the negative aspects of these legislations on the various categories of workers in the country.

\section{References}

Abbott, K., Pendlebury, N., \& Wardman, K. (2013). Business Law (9 ${ }^{\text {th }}$ ed.). Hampshire, UK: Cengage Learning EMEA.

Candide-Johnson, C. A., \& Shasore, O. (2012). Commercial Arbitration Law and International Practice in Nigeria. Pietermaritzburg: Interpak Books.

Chandra, B. D. (2008). Business Law. New Delhi: PHI Learning Private Limited.

Constitution of Nigeria, Third Alteration Act, 2010.

Docks (Safety of Labour) Regulations.

Factories Act, 1987.

Fashoyin, T. (1992). Industrial Relations in Nigeria (2 ${ }^{\text {nd }}$ ed.). Lagos: Longman Nigeria Plc. Labour Act, 1974.

Macintyre, E. (2008). Business Law. Essex, UK: Pearson Education Limited.

National Industrial Court Act, 2006.

National Industrial Court of Nigeria (Civil Procedure) Rules, 2016.

Nwocha, M. E. (2016). Customary Law, Social Development and Administration of Justice in Nigeria. Beijing Law Review, 7, 430-442. https://doi.org/10.4236/blr.2016.74034

Trade Disputes Act, 2006.

Trade Unions (Amendment) Act, 2005.

Trade Unions Act, 1973.

Uvieghara, E. E. (2001). Labour Law in Nigeria. Lagos: Malthouse Press Ltd. 
Submit or recommend next manuscript to SCIRP and we will provide best service for you:

Accepting pre-submission inquiries through Email, Facebook, LinkedIn, Twitter, etc. A wide selection of journals (inclusive of 9 subjects, more than 200 journals)

Providing 24-hour high-quality service

User-friendly online submission system

Fair and swift peer-review system

Efficient typesetting and proofreading procedure

Display of the result of downloads and visits, as well as the number of cited articles Maximum dissemination of your research work

Submit your manuscript at: http://papersubmission.scirp.org/

Or contact blr@scirp.org 